\title{
ANALISIS PENGARUH KINERJA GURU DALAM PEMBELAJARAN DAN PERSEPSI SISWA ATAS LINGKUNGAN BELAJAR TERHADAP HASIL BELAJAR
}

\author{
Nurdin $^{1}$, Hery Purwosusanto ${ }^{2}$, Tjipto Djuhartono ${ }^{3(*)}$ \\ Universitas IndraprastaPGRI Jakarta, Indonesia \\ Dr.nurdin3067@yahoo.com ${ }^{1}$, terussmart@gmail.com ${ }^{2}$, tjiptodjuhartono@gmail.com ${ }^{3}$
}

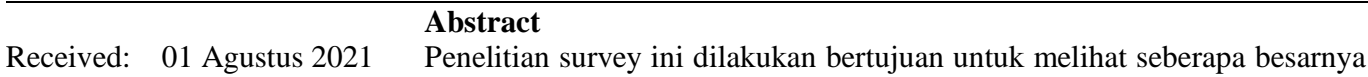
Revised: 21 Agustus 2021 pengaruh kinerja guru dalam proses pembelajaran dan persepsi siswa atas Accepted: 14 September 2021 lingkungan belajar. Lingkungan belajar yang baik membuat guru melaksanakan proses pembelajaran yang baik dan siswa dapat mengikuti pelajaran dengan sebaik-baiknya, sehingga hasil belajar siswa bisa dicapai dengan baik. Sampel Penelitian ini sebanyak 80 orang siswa di SMA Negeri 5 Tambun Bekasi. Teknik pengumpulan data dengan menggunakan kuesioner.Keabsahan data diperoleh dengan uji validitas dan reliabilitas, semua data memiliki distribusi normal. Data dianalisis menggunakan korelasi regresi. Hasil penelitian membuktikan bahwa kinerja guru dalam proses pembelajaran memberikan pengaruh yang signifikan terhadap hasil belajar mata pelajaran ekonomi atau ilmu pengetahuan sosial. Begitu juga persepsi siswa atas lingkungan belajar memberi pengaruh yang signifikan terhadap hasil belajar mata pelajaran ekonomi atau ilmu pengetahuan sosial. Temuan juga menunjukkan bahwa kinerja guru dalam proses pembelajaran dan persepsi siswa atas lingkungan belajar secara bersamasama mempunyai hubungan yang kuat terhadap hasil belajar mata pelajaran ekonomi atau ilmu sosial.
\end{abstract}

Keywords: Hasil belajar, Pembelajaran, Persepsi

(*) Corresponding Author: D Djuhartono, tjiptodjuhartono@gmail.com, +62 8129967504

How to Cite: Nurdin, Purwosusanto, H., \& Djuhartono, T. (2021). Analisis Pengaruh Kinerja Guru Dalam Pembelajaran Dan Persepsi Siswa Atas Lingkungan Belajar Terhadap Hasil Belajar. Research and Development Journal of Education, 7 (2), 434-444.

\section{INTRODUCTION}

Pembelajaran merupakan faktor determinan bagi keberhasilan mutu pendidikan, untuk itu guru sangat diharapkan dapat melaksanakan pembelajaran dengan sebaikbaiknya dan diharpkan dapat memainkan perang yang sangat penting terutama berusaha untuk membantu peserta didik dan membangun sikap positif dalam mengikuti proses belajar-mengajar. Peranan seorang guru merupakan salah satu faktor yang sangat penting untuk menentukan keberhasilan suatu proses belajar mengajar di kelas. Dimasa yang akan datang kegiatan pembelajaran bukan lagi mempersiapkan peserta didik yang bersifat pasif dan diharapkan bersifat aktif, oleh karena itu peserta didik juga sangat diharapkan berpengetahuan yang senang tiasa mampu menyerap materi ajar yang diberikan oleh guru dan mampu menyesuaikan diri dengan informasi baru dengan berfikir positif, bertanya, menggali, mencipta, dan mengembankang cara-cara tertentu yang berkaitan dengan kebutuhannya. Tujuan umum pendidikan ekonomi atau ilmu pengetahuan sosial pada jenjang pendidikan menengah memberi tekanan pada penalaran, dasar dan pembentukan sikap siswa dimasa yang akan datang.

Guru dihadapkan dengan perosalan-persoalan yang makin kompleks, terlebih derasnya arus globalisasi yang tidak bisa terbendung, sehingga dengan mambangun 
manusia masa depan yang berwawsan nasionalisme kebangsaan dan budaya makin sulit. Kesulitan-kesulitan tersebut akan berdampak pada kualitas kinerja guru dalam melaksanakan pembelajaran. Guru sebagai pengelola kelas diharapkan dapat meningkatkan perannya dan juga diharapkan memiliki kemampuan untuk mengelola kelas sehingga hasil belajar siswa bisa dicapai dengan optimal. Keberhasilan belajar selain ditentukan oleh kinerja guru yang baik terutama dalam melaksanakan proses pembelajaran juga akan ditentukan oleh lingkungan belajar yang baik (Soejadi, 1991: 4). Lingkungan belajar diantaranya: lingkungan sekolah, yaitu: sarana dan prasarana yang baik, lingkungan keluarga, dan lingkungan masyarakat. Menurut Rusyan (1999: 148) menyatakan bahwa lingkungan belajar adalah segala hal yang berada di sekitar kita yang dapat mempengaruhi hasil belajar siswa. Mata pelajaran ilmu ekonomi atau IPS merupakan pengetahuan dasar yang diperlukan oleh peserta didik untuk menunjang keberhasilan belajarnya dalam menempuh pendidikan yang lebih tinggi. Bahkan ilmu ekonomi diperlukan oleh semua orang dalam kehidupan sehari-hari.

\section{LITERATURE REVIEW}

\section{Hasil Belajar}

Hasil belajar dapat dijadikan indikator untuk mengetahui keberhasilan suatu perlakuan pembelajaran (Soejadi, 1991: 10). Reigeluth (1994, 14) menyatakan bahwa ukuran keberhasilan suatu perlakuan pembelajaran dapat dikelompokkan atas tiga bagian, yaitu: (1) keefektifan diukur dari tingkat pencapaian siswa sesuai apa yang telah dipelajari, (2) efisiensi diukur dari rasio waktu yang dipakai dengan biaya yang digunakan, (3) proses pembelajaran yang sangat menyenangkan dapat diukur dengan mengamati kecenderungan siswa untuk tetap dan terus belajar terkait dengan bidang yang akan dipelajari. Hasil belajar termasuk dalam kelompok atribut kognitif yang respons hasil pengukurannya tergolong pendapat (judgment), yaitu respon yang dapat dinyatakan benar atau salah (Suryabrata, 2007: 19). Briggs (1979: 149), menyatakan bahwa hasil belajar adalah merupakan seluruh kecakapan dan segala hal yang diperoleh melalui suatu proses belajar- mengajar di dalam ruangan belajar. Hal tersebut dapat ditapsirkan bahwa hasil belajar yang diperoleh dengan baik karena siswa telah melakukan suatu usaha dengan sebaik-baiknya. Soedijarto (1993: 49), mengemukakan bahwa hasil belajar adalah merupakan suatu bukti penguasaan materi pelajaran yang telah diperoleh oleh siswa setelah melalui proses belajar- mengajar berdasakan tujuan pendidikan nasional yang telah ditetapkan. Dengan demikian belajar dilakukan untuk menguasahakan adanya perubahan perilaku seorang siswa setelah mengikuti pelajaran dengan sebaik-bainya, perubahan perilaku tersebut merupakan suatu bukti yang nyata setelah mengikuti proses belajar-mengajar dengan baik. Hasil belajar yang baik dapat diukur dengan mereflesikan tujuan proses belajar-mengajar yang baik (Gronlund, 1997: 20).

Miarso dan Degang (2004: 550-551), menyatakan bahwa terdapat empat rujukan yang terkandung dalam proses belajar-mengajar, yaitu: (1) terdapat suatu perubahan atau pengetahuan yang baru, (2) perubahan atau pengetahuan yang baru itu tidak berlangsung sesaat, melainkan menetap dan dapat disimpan, (3) perubahan atau pengetahuan yang baru itu terjadi karena adanya suatu usaha yang sungguh-sungguh , dan (4) perubahan atau pengetahuan yang baru itu tidak hanya timbul karena faktor pertumbuhan. Pendapat Mulyasa (dikutip Rapi, 2016: 70) mengemukakan bahwa hasil belajar adalah suatu prestasi belajar yang dicapai oleh peserta didik secara keseluruhan yang menjadi indikator kompetensi yang baik dan merupakan suatu proses 
perubahan tingkah laku. Begitu juga pendapat Hergenhahn dan Olson (dikutip Rapi, 2016:70) menunjukkan bahwa hasil belajar harus selalu diterjemahkan ke dalam perilaku atau tindakan yang dapat diamatai. Salah satu faktor yang berpengaruh terhadap hasil belajar adalah cara guru melaksanakan pembelajaran. Berpijak dari uraian diatas, diperoleh dua hal pokok, yaitu: (a) hasil belajar merupakan akibat dari proses pembelajaran, dan (b) hasil belajar dapat dijadikan indikator untuk mengetahui keberhasilan proses belajar-mengajar.

\section{Kinerja Guru dalam Pembelajaran}

Kinerja merupakan upaya sistematik dari suatu profesi melalui diskripsi akurat tentang pengetahuan, keterampilan, dan kemampuan dalam tampilan kecakapan kerja sebagai guru khususnya dalam pembelajaran di kelas. Sutisna (2000: 17) menyatakan guru adalah pendidik atau orang dewasa yang mempunyai tanggungjawab untuk memberi bimbingan atau bantuan kepada anak didiknya dalam perkembangan jasmani dan rohaninya agar mencapai kedewasaannya, mampu berdiri sendiri dan mempunyai kemampuan dalam melaksanakan tugasnya sebagai makhluk Allah di muka bumi, sebagai makhluk sosial yang sanggup berdiri sendiri. Guru yang profesional sangat diharpkan untuk meningkatkan mutu pendidikan begitu juga memegang peranan yang sangat penting mengelola pembelajaran sesuai prinsip-prinsip pembelajaran. Guru diharapkan lebih kreatif dalam melaksanakan pembelajaran dengan baik sehingga siswa dapat berkembang seoptimal mungkin. Menurut Hilgard ( 1982: 82) menyatakan bahwa kinerja merupakan hasil kerja seseorang setelah melakukan suatu usaha sesuai pengetahuan yang dimilikinya yang dapat diamati oleh orang lain . Whitmore (1997: 21) menyatakan bahwa kinerja seorang guru dapat dicapai dengan baik apabila guru dapat melaksanakan pembelajaran sesuai stadar mutu pendidikan yang secara langsung maupun tidak langsung dapat diamati oleh siswa. Kinerja dapat dicapai apabila guru memiliki motivasi yang tinggi untuk melaksanakan pembelajaran dengan baik. Menurut Djamarah (2002: 64) menyatakan bahwa pengetahuan dan kemampuan tentang tugas akan menentukan kinerja seseorang. Mathis dan Jackson (2002: 78) menyatakan bahwa kinerja seorang guru dapat dicapai dengan baik memiliki beberapa kriteria yang perlu dipenuhi, diantaranya: (1) berorientasi pada prestasi, (2) percaya diri, (3) pengendalian diri, dan (4) kompestensi yang baik .

Pendapat Rusman (dikutip Krissandi dan Rusmawan, 2015: 463) mengemukakan bahwa sumberdaya pendidikan perlu disiapkan dengan baik, diantaranya: sarana maupun prasarana, biaya yang cukup, organisasi yang sesuai, dan lingkungan sekolah merupakan faktor utama yang sangat menentukan berhasil atau tidaknya pendidikan, dan faktor yang utama adalah guru yang disiplin. Guru yang disiplin sangat diharapkan untuk melaksanakan pembelajaran dan kunci keberhasilan suatu pendidikan tergantung pada kualitas guru. Berdasarkan undang-undang sistem pendidikan nasional nomor 2 (2003) pasal 39 ayat 2 disebutkan bahwa guru sebagai pendidik yang profesional yang mempunyai tugas untuk merencanakan dan berusaha melaksanakan proses pembelajaran dengan sebaik-baiknya, berusaha menilai hasil pembelajaran dengaa baik, melaksanakan pembimbingan dan pelatihan juga diharapkan dapat melakukan penelitian dan pengabdian kepada masyarakat. Selanjutnya pada pasal 40 ayat 2 dinyatakan terdapat tiga kewajiban-kewajiban guru, yaitu: (1) berusaha menciptakan suasana pendidikan yang sangat bermakna, sangat menyenangkan, berfikir kreatif, dinamis, dan logis, (2) mempunyai komitmen secara profesional dan berusaha untuk meningkatkan mutu pendidikan yang lebih baik, dan (3) memberi teladan yang baik dan menjaga nama baik suatu lembaga, suatu profesi, dan kedudukan sesuai dengan kepercayaan yang diberikan kepadanya. Guru dalam komponen sistem pendidikan 
memiliki peranan yang baik untuk menentukan keberhasilan peserta didik, terutama dalam menciptakan proses dan hasil belajar yang berkualitas. Untuk itu perlu diupayakan agar pembelajaran dapat dilaksanakan denga baik maka diperlu guru yang memiliki kualitas yang baik. Jika tujuan belum tercapai guru perlu mengkaji dan mengatur kembali situasi pembelajaran, dengan cara menilai sistem pembelajaran, hasil belajar, dan memimpan dengan dituntut oleh tujuan (Davies, 1997: 29). Dalam konteks pembelajaran sebagai sistem, maka evaluasi akan berfungsi sebagai pemantau kinerja komponen-komponen sistem dalam mencapai tujuan akhir pembelajaran dan selanjutnya dapat dijadikan bahan pertimbangan untuk kebijakan dan pengembangan pembelajaran dimasa yang akan datang.

\section{Persepsi Siswa Atas Lingkungan Belajar}

Pendapat Rakhmat (dikutip Krissandi dan Rusmawan, 2015:458) mengemukakan bahwa persepsi adalah pengalaman yang diperoleh mengenai suatu objek, peristiwa, atau hubungan-hubungan yang diperoleh dengan menyampaiakan sebuah informasi dan melampirkan sebuah kesan.Kesan yang diterima seseorang sangat tergantung pada seluruh pengalaman yang telah diperoleh melalui proses berfikir yang positif dan belajar, juga dapat dipengaruhi oleh faktor yang berasal dari dalam diri individu. Rasyad (2001: 5) menyatakan bahwa persepsi merupakan suatu proses pengamatan siswa yang berasal dari suatu kognisi secara terus-menerus dan dapat dipengaruhi oleh informasi yang baru dari lingkungan disekitarnya. Menurut Robbins (2003: 17) menyatakan bahwa persepsi adalah sebagai proses di mana individu-individu diharapkan dapat mengorganisasikan dan menafsirkan kesan indra mereka agar memberi makna kepada lingkungann. Jika siswa memiliki persepsi yang baik kepada guru, maka siswa dapat mengikuti pelajaran dengan sungguh-sungguh yang memungkinkan hasil belajarnya bisa dicapai dengan sebaik-baiknya.

Lingkungan belajar menurut Hamalik (2000: 47) yaitu suatu tempat yang dapat digunakan untuk melaksanakan proses belajar-mengajar supaya dapat melaksanakan komunikasi yang baik antara siswa dengan guru. Kemudian menurut Winkel (1996:25) menyatakan bahwa lingkungan belajar adalah suatu tempat yang dapat dipakai untuk melaksanakan proses belajar-mengajar suspaya bisa memperoleh pengetahuan, pemahaman, keterampilan, dan sikap yang bisa membuat siswa lebih dewasa dan berpikir lebih baik. Menurut Purwanto (2000:28) menyatakan bahwa lingkungan adalah semua kondisi-kondisi dalam dunia ini yang ada dalam cara-cara tertentu dapat mempengaruhi tingkah laku sesseorang. Pengaruh lingkungan terhadap diri seseorang dapat mendorong menjadi baik, ataupun sebaliknya dapat mengubah yang semula baik menjadi kurang baik. Selanjutnya dikatakan bahwa lingkungan sekolah yang baik adalah dapat dipengaruhi tiga faktor, yaitu: (1) lingkungan keluarga adalah dimana orang tua pemimpin keluarga yang perlu memiliki tanggung jawab mengenai keselamatan keluarganya, (2) lingkungan sekolah adalah suatu lembaga dengan organisasi yang sudah tersusun rapi mempunyai fungsi sebagai pusat pendidikan untuk pembentukan pribadi siswa, dan (3) lingkungan masyarakat adalah mempunyai peranan untuk menunjang menyelenggarakan pendidikan.

Pendapat Dupper (dikutip Wuryandani dan Ambarwati, 2016: 213) menyatakan bahwa iklim lingkungan sekolah yang baik sangat diperluan suatu kondisi yang kondusif dengan memperhatikan beberapa hal, sebagai berikut: (1) keadaan fisik sekolah yang lebih baik, (2) memiliki upaya untuk membangun, memelihara hubungan yang peduli, saling menghormati, selalu memberi dukungan, dan kolaboratif sesama anggota staf sekolah, maupun sesama siswa, dan keluarga, (3) siswa diharpkan dapat berpartisipasi aktif dalam pengambilan suatu keputusan, (4) siswa menganggap bahwa 
aturan yang telah dibuat sebagai hal yang jelas, (5) sekolah aman bagi siswa, keluarga, dan guru, (6) selalu tersedia layanan belajar yang baik, (7) sekolah memiliki tingkat akademik yang tinggi dan selalu diupayakan memberikan dukungan untuk pencapaian tujuan, (8) memiliki upaya untuk selalu mengembangkan kemampuan bersosialisasi dan menjaga emosionalnya untuk semua siswa, (9) guru sebagai model dan selalu memelihara sikap yang dapat ditiru, dan (10) memandang orang tua sebagai anggota masyarakat dan juga sebagai sumber daya yang sangat berharga, dan mereka berusaha mendorong untuk terlibat secara aktif di lingkungan sekolah. Kemudian pendapat Rusman dikutip Krissandi dan Rusmawan (2015: 463) menyatakan bahwa iklin lingkungan belajar yang baik atau sumber daya pendidikan merupakan faktor yang sangat penting perlu disediakan untuk dapat menunjang tercapai tujuan pendidikan yang diharpkan. Hal tersebut mengandung bahwa bahwa iklim lingkungan belajar perlu disipakan dengan sebaik-baiknya supaya dapat memperlancar proses belajarmengajar supaya hasil belajar peserta didik dapat dicapai dengan baik. Menurut Rusyan (1999: 148) mengemukakan bahwa iklim lingkungan belajar adalah segala sesuatu yang berada di sekitar kita yang berpengaruh terhadap diri siswa. Dengan demikian iklim lingkungan belajar adalah semua kondisi yang berada di sekitar kita yang dapat mendukung proses belajar-mengajar sehingga hasil belajar siswa dapat dicapai dengan baik.

Menurut Slameto (2003: 2) menyatakan bahwa belajar merupakan suatu proses usaha yang dilakukan oleh peserta didik untuk memperoleh pengetahuan, perubahan sikap, dan perubahan tingkah laku yang baik supaya dapat dicontoh oleh orang lain, sebagai hasil pengalamannya sendiri supaya dapat berinteraksi bersama orang-orang yang ada di lingkungannya. Menurut Sardiman (2007:21) menyatakan bahwa belajar adalah suatu usaha untuk mengubah pengetahuan dan tingkah laku seseorang. jadi belajar itu membawa suatu perubahan pada individu-individu yang belajar. Dengan demikian dapat dikatakan bahwa belajar itu sebagai rangkaian kegiatan untuk menuju perkembangan pribadi manusia seutuhnya. Belajar dalam pengertian ini difokuskan pada tercapainya daya pikir dan tindakan yang berkualitas untuk memecahkan masalahmasalah yang dihadapi peserta didik. Sedangkan menurut Djamarah (2002:16) menyatakan bahwa belajar pada dasarnya sebagai tahapan perubahan pengetahuan dan tingkah laku individu yang bersifat menetap sebagai hasil interaksi dengan lingkungan yang terjadi karena ada tujuan yang akan dicapai dengan mencakup seluruh aspek tingkah laku. Dalam belajar sangat diperlukan fasilitas yang baik sehingga proses belajar-mengajar dapat terlaksana dengan sebaik-baiknya. Menurut Arikunto (2001:37) menyatakan banwa fasilitas belajar adalah segala sesuatu yang dapat memudahkan dan melancarkan pelaksanaan proses belajar -mengajar. Sedangkan menurut Sudirman (1992: 6) menyatakan bahwa fasilitas belajar adalah segala sesuatu untuk mempermudah suatu usaha yang ingin dicapai oleh peserta didik. Dalam kamus besar bahasa Indonesia (2004:314) fasilitas belajar adalah segala hal yang dapat memudahkan suatu usaha sehingga tujuan bisa dicapai dengan baik.

\section{METHODS}

Penelitian ini merupakan penelitian survey. Variabel terikatnya adalah hasil belajar mata pelajaran ekonomi atau ilmu pengetahuan sosial, variabel bebasnya yaitu kinerja guru dalam proses pembelajaran dan persepsi siswa atas lingkungan belajar. Penelitian ini dilaksanakan di SMA Negeri 5 Tambun-Bekasi pada tahun ajaran 2020/2021. Subjek penelitian sebanyak 80 orang siswa diambil secara acak, pengumpulan data menggunakan 
kuesioner dengan skala likert. Keabsahan data diperoleh dengan uji validitas dan reliabilitas.

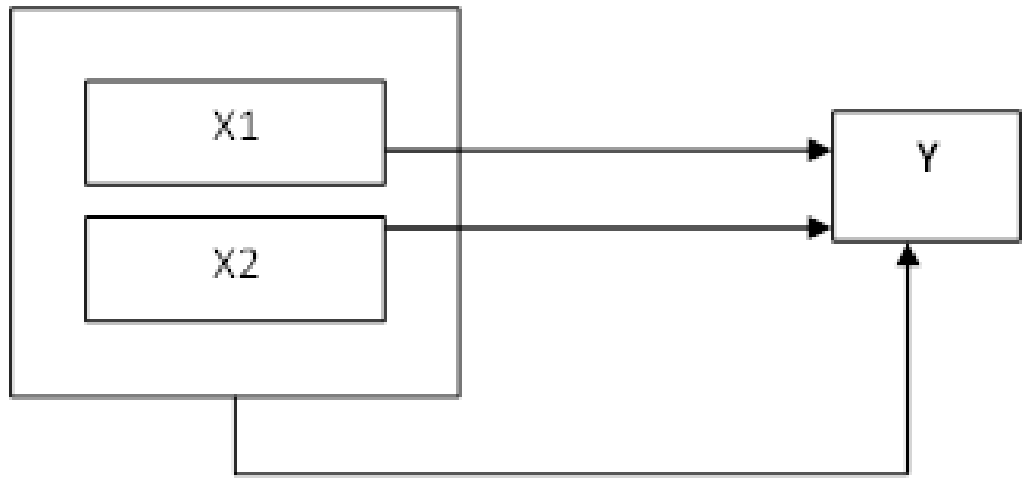

\section{Gambar 2.}

Konstalasi Penelitian

Sumber: Peneliti

Keterangan :

$\mathrm{Y}=$ Hasil belajar mata pelajaran ekonomi atau ilmu pengatahuan sosial

$\mathrm{X} 1=$ Kinerja guru dalam proses pembelajaran

$\mathrm{X} 2=$ Persepsi siswa atas lingkungan belajar

\section{RESULTS \& DISCUSSION}

\section{Result}

\section{Uji Persyaratan Analisis}

Berdasarkan hasil uji normalitas pada tingkat @ 0,05 subjek penelitian memiliki distribusi normal yang terdapat pada gambar 1 .

Tabel 1.

Hasil Pengujian Normalitas Data Dengan Bantuan Program SPSS

\begin{tabular}{ccc}
\hline & & Unstandardized Residual \\
\hline Normal Parameters & & 80 \\
& Mean &, 0000000 \\
& Std. Deviation & 7,76543253 \\
& Absolute &, 064 \\
& Positive &, 057 \\
& Negative &,- 056 \\
Test Statistic & &, 056 \\
Asymp. Sig. (2-tailed) &, 230 \\
\hline
\end{tabular}

Sumber: Data Diolah Peneliti

Pada baris Asymp. Sig (2 tailed) untuk galat baku persamaan regresi linier berganda sebesar $0,230>0,05$. Maka persamaan regresi galat baku berdistribusi normal karena memiliki nilai asymp sig >0,05.Untuk memperkuat hasil pengujian tersebut juga ditampilkan Grafik Normal P-P Plot of Regression Standarized Residual sebagai berikut. 


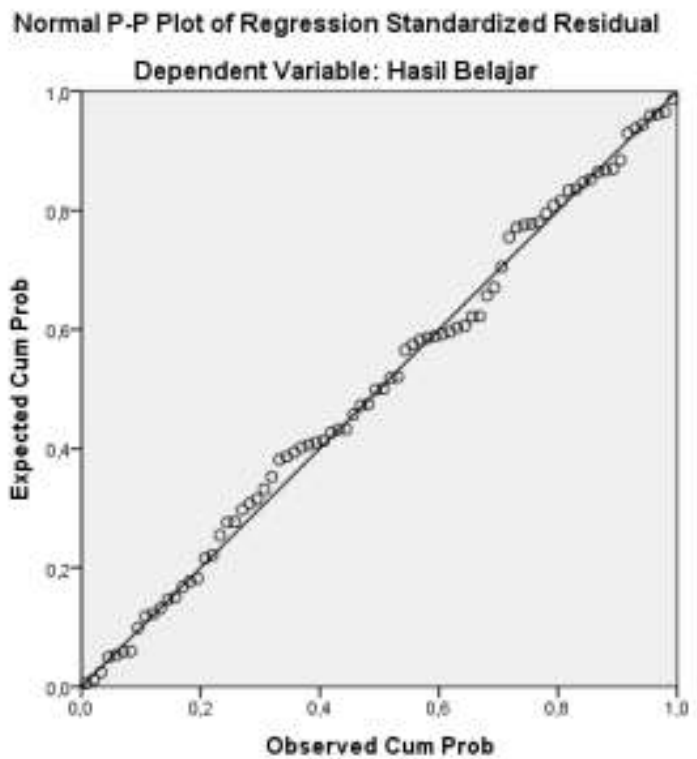

Gambar 1.

Kurva Normalitas

Sumber: Data Diolah Peneliti

Tabel 2.

Uji Linearity Persamaan Regresi Kinerja Guru Dalam Proses Pembelajaran Terhadap Hasil Belajar Mata Pelajaran Ekonomi Atau Ilmu Pengetahuan Sosial

\begin{tabular}{|c|c|c|c|c|c|c|c|}
\hline & & & $\begin{array}{c}\text { Sum of } \\
\text { Squares }\end{array}$ & Df & Mean Square & $\mathbf{F}$ & Sig. \\
\hline \multirow{5}{*}{$\begin{array}{c}\text { Hasil Belajar * } \\
\text { Kinerja Guru } \\
\text { Dalam } \\
\text { Pembelajaran }\end{array}$} & Between & (Combined) & 2058,092 & 16 & 128,056 & 2,902 & ,004 \\
\hline & Groups & Linearity & 1246,137 & 1 & 1763,865 & 23,073 &, 000 \\
\hline & & $\begin{array}{l}\text { Deviation from } \\
\text { Linearity }\end{array}$ & 765,832 & 15 & 58,289 & 1,128 & ,327 \\
\hline & Witl & in Groups & 3289,648 & 62 & 51,786 & & \\
\hline & & Total & 5375,97 & 79 & & & \\
\hline
\end{tabular}

Sumber: Data Diolah Peneliti

Kriteria pengujian dimana nilai sig $=0,327>0,05$ berarti persamaan regresi kinerja guru dalam proses pembelajaran terhadap hasil belajar mata pelajaran ekonomi atau ilmu pengetahuan sosial adalah linier.

Tabel 3.

Uji Linearity Persamaan Regresi Persep Siswa Atas Lingkungan Belajar Terhadap Hasil Belajar Mata Pelajaran Ekonomi Atau Ilmu Pengetahuan Sosial

\begin{tabular}{|c|c|c|c|c|c|c|c|}
\hline & & & $\begin{array}{c}\text { Sum of } \\
\text { Squares }\end{array}$ & df & Mean Square & $\mathbf{F}$ & Sig. \\
\hline Hasil Belajar & Between & (Combined) & 1718,532 & 15 & 123,902 & 2,174 & ,026 \\
\hline Persepsi Siswa atas & Groups & Linearity & 473,067 & 1 & 570,907 & 7,095 & ,005 \\
\hline \multirow[t]{3}{*}{ Lingkungan Belajar } & & $\begin{array}{l}\text { Deviation } \\
\text { from } \\
\text { Linearity }\end{array}$ & 1234,368 & 14 & 78,654 & 1,867 & ,248 \\
\hline & Withi & Groups & 3670,765 & 63 & 58,754 & & \\
\hline & & otal & 5278,165 & 79 & & & \\
\hline
\end{tabular}

Sumber: Data Diolah Peneliti 
Kriteria pengujian dimana nilai sig $=0,248>0,05$ berarti persamaan regresi persepsi siswa atas lingkungan belajar terhadap hasil belajar mata pelajaran ekonomi atau ilmu pengetahuan sosial adalah linear. brikut :

Berdasarkan teknik analisis data maka dapat disajikan hasil penelitian sebagai

Tabel 4.

Koefisien Regresi Ganda dan Tingkat Signifikansinya

\begin{tabular}{|c|c|c|c|c|c|c|}
\hline \multirow{2}{*}{\multicolumn{2}{|c|}{ Model }} & \multicolumn{2}{|c|}{$\begin{array}{l}\text { Unstandardized } \\
\text { Coefficients }\end{array}$} & \multirow{2}{*}{$\begin{array}{c}\text { Standardized } \\
\text { Coefficients } \\
\text { Beta } \\
\end{array}$} & \multirow[t]{2}{*}{$\mathbf{t}$} & \multirow[t]{2}{*}{ Sig. } \\
\hline & & B & Std. Error & & & \\
\hline \multirow[t]{3}{*}{1} & (Constant) & 5,086 & 13,987 & & 328 & ,658 \\
\hline & Kinerja Guru dalam Pembelajaran & ,862 & ,208 & ,478 & 4,683 & 000 \\
\hline & $\begin{array}{l}\text { Persepsi Siswa atas Lingkungan } \\
\text { Belajar }\end{array}$ &, 736 & ,219 & ,283 & 3,872 & ,004 \\
\hline
\end{tabular}

Sumber: Data Diolah Peneliti

Kinerja guru dalam pembelajaran berpengaruh secera signifikan terhadap hasil belajar mata pelajaran ekonomi atau ilmu pengetahuan sosial.

Kriteria pengujian: Nilai $t_{\text {hitung }}=4,683>$ nilai sig $=0.000$ pada @ 0.05 .

Persepsi siswa atas lingkungan belajar berpengaruh secara signifikan terhadap hasil belajar mata pelajaran ekonomi atau ilmu pengetahuan sosial.

Kriteria pengujian : Nilai $t_{\text {hitung }}=3,872>$ nilai sig $=0.005$ pada @ 0.04 .

Tabel 5.

Pengujian Koefisien Regresi Linear Ganda

\begin{tabular}{lllllll}
\hline & Model & Sum of Squares & Df & Mean Square & F & Sig. \\
\hline 1 & Regression & 1097,345 & 2 & 707,135 & 17,468 &, $000^{\mathrm{b}}$ \\
Residual & 3568,717 & 76 & 48,087 & & \\
Total & 5463,063 & 78 & & & \\
& & & & & &
\end{tabular}

Sumber: Data Diolah Peneliti

Kinerja guru dalam proses pembelajaran dan persepsi siswa atas lingkungan belajar secara bersama-sama memberi pengaruh yang signifikan terhadap hasil belajar mata pelajaran ekonomi atau ilmu pengetahuan sosial.

Kriteria pengujian: Nilai $F_{\text {hitung }}=17,468>$ nilai sig $=0.000$ pada @ 0.05 .

Tabel 6.

Koefisien Korelasi Ganda, dan Koefisien Determinasi

\begin{tabular}{ccccc}
\hline Model & R & R Square & $\begin{array}{c}\text { Adjusted R } \\
\text { Square }\end{array}$ & $\begin{array}{c}\text { Std. Error of } \\
\text { the Estimate }\end{array}$ \\
\hline 1 &, 878 &, 784 &, 277 & 6,87642 \\
\hline Sumber: Data Diolah Peneliti & & &
\end{tabular}

Nilai koefisien determinasi $(\mathrm{R})^{2}$ sebesar $78,4 \%$ artinya kinerja guru dalam proses pembelajaran dan persepsi siswa atas lingkungan belajar mempunyai hubungan yang kuat terhadap hasil belajar mata pelajaran ekomomi atau ilmu pengetahuan sosial, sedangkan sisanya $21,6 \%(100 \%-78,4 \%)$ tidak dianalisis dalam penelitian ini. 


\section{Discussion}

1. Kinerja guru dalam proses pembelajaran berpengaruh signifikan terhadap hasil belajar mata pelajaran ekonomi atau ilmu pengetahuan sosial

Sesuai hasil penelitian, dengan mengacu pendapat Whitmore (1997: 21) menyatakan bahwa kinerja adalah merupakan suatu aktifitas yang baik secara langsung dapat diamatai oleh orang lain. Kemudian dengan mengacu pendapat Sutisna (2000: 17) menyatakan guru adalah pendidik yang bertanggung jawab berusaha memberi bimbingan kepada anak didiknya dalam perkembangan jasmani dan rohaninya agar mencapai kedewasaannya, mampu berdiri sendiri dan dapat melaksanakan tugasnya sebagai makhluk Allah di muka bumi, dan juga sebagai makhluk sosial diharapkan dapat berdiri sendiri.Guru juga memiliki peran untuk menentukan keberhasilan belajar siswa, oleh karena itu upaya peningkatan hasil belajar yang lebih baik perlu mendapat dukungan oleh guru yang punya tanggung jawab dalam melaksanakan tugasnya dengan baik. Dengan mengacu pendapat Davies (1997: 29) menyatakan bahwa jika tujuan pembelajaran belum dapat tercapai dengan baik, guru perlu menkaji dan mengatur kembali proses pembelajaran, dengan cara menilai sistem pembelajaran. Oleh karena itu guru sangat diharapkan untuk dapat melaksanakan proses pembelajaran dengan sebaik-baiknya supaya hasil belajar siswa dapat dicapai sesuai standar yang telah ditetapkan.

2. Persepsi siswa atas lingkungan belajar berpengaruh signifikan terhadap hasil belajar mata pelajaran ekonomi atau ilmu pengetahuan sosial

Sesuai hasil penelitian, dengan mengacu pendapat Robbins (2003: 17) menyatakan bahwa persepsi merupakan suatu proses dimana siswa diharapkan dapat mengorganisasikan dan dapat menafsirkan kesan indera mereka supaya memberi mamfaat yang baik kepada lingkungan. Kemudian dengan mengacu pendapat Rasyad (2001: 5) menyatakan bahwa persepsi merupakan suatu proses pengamatan siswa yang berasal dari suatu kognisi secara terus-menerus dan dapat dipengaruhi oleh informasi baru dari lingkungannya. Kemudian dengan mengacu pendapat Winkel (1996:25) berpendapat bahwa lingkungan belajar adalah merupakan suatu tempat untuk memperoleh pengetahuan, pemahaman, keterampilan,dan maupun sikap yang mengantarkan kedewasaan kepada siswa. Pendapat Rusman dikutip Krissandi dan Rusmawan ( 2015: 463) menyatakan bahwa iklim lingkungan belajar yang baik merupakan salah satu faktor yang perlu diperhatikan supaya proses belajar-mengajar dapat terlaksanakan dengan baik sehingga tujuan pendidikan dapat dicapai. Artinya lingkungan belajar perlu disiapkan dengan baik supaya proses belajar-mengajar dapat terlaksanan sesuai tujuan proses belajar-mengajar yang sudah direncanakan dengan baik. Jadi jika siswa memiliki persepsi yang baik kepada guru dan didukung oleh iklim lingkungan belajar yang baik, maka siswa dapat mengikuti pelajaran dengan sungguh-sungguh yang memungkinkan hasil belajarnya bisa dicapai dengan baik.

3. Kinerja guru dalam pembelajaran danpersepasi siswa atas lingkungan belajar secara bersama-sama berpengaruh signifikan terhadap hasil belajar mata pelajaran ekonomi atau ilmu pengetahuan sosial

Sesuai hasil penelitian, dengan mengacu pendapat Hilgard (1982: 82) menyatakan bahwa kinerja adalah merupakan suatu perilaku yang baik dan dapat diamati oleh orang lain. Guru sebagai pendidik yang baik diharpkan dapat melaksanakan pembelajaran dengan sebaik-bakinya dan kunci keberhasilan suatu pendidikan tergantung pada kinerja guru. Berdasarkan undang-undang sistem 
pendidikan nasional nomor 2 (2003) pasal 39 ayat 2 disebutkan bahwa guru merupakan tenaga profesional yang tugas utamanya yaitu berusaha dengan baik untuk merencanakan dan melaksanakan proses pembelajaran dengan baik, menilai hasil pembelajaran dengan sebaik-baiknya, berusaha melaksanakan pembimbingan dan pelatihan serta melakukan penelitian dan pengabdian kepada masyarakat. Bila dikaitkan dengan persepsi, Rasyad (2001: 53) menyatakan bahwa persepsi adalah merupakan suatu proses suatu pengamatan siswa yang sebenarnya dan dapat dipercayai dari suatu informasi yang benar dari lingkungannya. Dengan mengacu pendapat Hamalik (2000: 47) menyatakan bahwa iklim lingkungan belajar adalah merupakan suatu tempat untuk melakukan proses belajar mengajar sehingga diharapkan ada komunikasi yang baik antara siswa dan guru. Menurut Djamarah (2002:16) menyatakan bahwa belajar pada dasarnya sebagai tahapan perubahan tingkah laku individu yang bersifat menetap sebagai hasil interaksi dengan lingkungan yang terjadi karena ada tujuan yang akan dicapai dengan mencakup seluruh aspek tingkah laku. Kemudian dengan mengacu pendapat Slameto (2003: 2) menyatakan bahwa belajar yaitu suatu proses usaha yang dilakukan oleh siswa untuk memperoleh suatu perubahan baik pengetahuan maupun keterampilan. Jika guru melaksanakan poroses pembelajaran dengan baik dan persepsi siswa atas lingkungan belajar yang positif, maka hasil belajar siswa lebih baik

\section{CONCLUSION}

Hasil penelitian membuktikan bahwa kinerja guru dalam melaksanakan pembelajaran dan persepsi siswa atas lingkungan belajar secara simultan mempengaruhi hasil belajar mata pelajaran ekonomi atau ilmu pengetahuan sosial. Hasil belajar bisa lebih baik apabila kinerja guru lebih ditingkatkan karena siswa mempunyai persepsi positif sehingga dapat mengkuti pelajaran lebih baik. Temuan juga menunjukkan bahwa secara simultan mempunyai hubungan yang kuat terhadap hasil belajar mata pelajaran ekonomi atau ilmu pengetahuan sosial. Hal ini perlu dikaji lebih lanjut supaya hasil belajar dapat lebih ditingkatkan.

Berdasarkan simpulan yang diuraiakan di atas, maka saran dari penelitian ini dapat dikemukakan sebagai berikut:

1. Dalam upaya meningkatkan hasil belajar mata pelajaran Ekonomi atau ilmu pengetahuan sosial, hendaknya ditingkatkan sarana perpustakaan dan disiplin belajar sehingga para siswa selalu termotivasi untuk meningkatkan hasil belajarnya.

2. Peningkatan hasil belajar mata pelajaran Ekonomi atau ilmu pengetahuan sosial sebaiknya bisa ditempuh dengan cara meningkatkan sarana perpustakaan lebih baik. Peningkatan sarana perpustakaan ditempuh dengan selalu update buku-buku dan tata kelola perpustakaan sehingga diminati oleh siswa.

3. Guru perlu memberi motivasi kepada seluruh siswa, supaya disiplin dalam mengikuti prose belajar-mengajar dan dapat lebih ditingkatkan supaya hasil belajarnya dapat dicapai dengan sebaik-baiknya.

\section{REFERENCES}

Arikunto, Suharsini. (2001). Prosedur penelitian suatu pendekatan praktek. Jakarta: Rhineka Cipta.

Briggs, Lesle J. (1979). Introductional design, principles and aplication englewood cliffs. New Jersey: Printice Hall, ins. 
Davies, K Ivor. (1997). Instructional technigue. New York: McGraw-Hill Book Company.

Departemen Pendidikan dan Kebudayaan.(1989). Kamus umum bahasa Indonesia. Jakarta: Depdikbud.

Djamarah, Syaiful Bahri. (2002). Strategi belajar mengajar (Edisi revisi ). Jakarta: PT. Rineka Cipta.

Gronlund, Noman E. (1997). Constructing achievement test. Englewood Cliffs, NJ: Prentice Hall, Inc.

Hamalik, Oemar. (2000). Manajemen peningkatan mutu berbasis sekolah. Yogyakarta: FIP UNY.

Hilgard, Ernest R. (1982). Introduction to psychology. New York: Harcourt, Brace and World, Inc.

Krissandi, A D S, dan Rusmawan. (2015). Kendala guru sekolah sasar dalam implementasi kurikulum 2013? Cakrawala Pendidikan, XXXIV(3), 463.

Mathis, Robert L dan Jackson, Jhon H. (2002). Manajemen sumber daya manusia. Jakarta: Salemba Empat.

Miarso, Yusup Hadi dan Degang, I nyoma Sudana. (2004). Terapan teori kognitif dalam desain pembelajaran. Jakarta: Depdikbud.

Purwanto, M. Ngalim. (2000). Psikologi pendidikan. Bandung: Rosdakarya.

Rapi, N Ketut. (2016). Pengaruh model pembelajaran dan jenis penilaian formatif terhadap hasil belajar ipa siswa SMPN? Cakrawala Pendidikan, XXXV (1), 70.

Rasyad. (2001). Teori belajar dan pembelajaran. Jakarta: Uhamka Press.

Reigeluth, Charles M. (1994). Instructional design theories and model. New Jersey: Lawrence Eribaun associates.

Robbins, Stephen P. (2000). Organizational behavior. New Jersey: Prentice Hall.

Rusyan. (1999). Psikologi pendidikan. Bandung: Rosdakarya.

Sardiman A. M. (2007). Interaksi dan motivasi belajar mengajar. Jakarta: Rajawali Pers.

Slameto. (2003). Belajar dan faktor-faktor yang mempengaruhinya. Jakarta: Rineka Cipta.

Soedjadi. (1991). Mencari strategi pengelolaan pendidikan matematika menyongsong tinggal landas pembangunan Indonesia (Pidato Pengukuhan). Surabaya: IKIP Surabaya. . (1993). Menuju pendidikan nasional yang relevan dan bermutu. Jakarta: Balai Pustaka.

Sudirman, N. (1992). Ilmu pendidikan. Bandung: Remaja Rosdakarya.

Suryabrata, Sumadi. (2007). Pengembangan alat ukur psikologi. Yogyakarta: Andi Offset.

Sutisna, O. (2000). Administrasi pendidikan: dasar teoretis untuk praktek profesional. Bandung: Penerbit Angkasa.

Undang-Undang Republik Indonesia Nomor 20 Tahun 2003. Tentang sistem pendidikan nasional. Jakarta: Departeman Pendidikan Nasional Republik Indonesia.

Whitmore, Jhon. (1997). Coaching forp permoncance. Purnomo. Jakarta: Gramedia Pustaka Utama.

Winkel, W. S. (1996). Psikologi pengajaran. Jakarta: Gramedia.

Wuryandani, W. Fathurrohman, dan Ambarwati, U. (2016).“Implementasi Pendidikan Karakter Kemandirian Di Muhammadiyah Boarding School”. dalam Cakrawala Pendidikan. Jurnal Ilmiah Pendidikan XXXV (2) hlm 213. 